\title{
GOLDEN EAGLES ATTACK WHITE-FRONTED GEESE
}

\author{
by ERNIE KUYT*
}

Food habits of Golden Eagles have been discussed by a number of authors, particularly by researchers in Montana and portions of the southwestern U.S.A. " $: 3467$ Lagomorphs were the principal prey taken. Bird remains found near eagle nest sites and in pellets were of much lesser importance. Smith reported eagles killing domestic geese but noted that such predation on domestic species was negligible." Further north, Whitfield et al. reported similar eagle food habits with Common Raven feathers the only bird remains identified to species. "1" Murie considered the Golden Eagle's effect on bird life in Alaska's Mount McKinley area to be insignificant. ${ }^{\text {}}$ Höhn's record of a Golden Eagle knocking down a White-fronted Goose near the Anderson River is the most pertinent one."

During the spring and summer of 1972, the Canadian Wildlife Service carried out waterfowl studies in the N.W.T. from base camps at the mouths of the Anderson River $\left(69^{\circ} 42^{\prime} \mathrm{N}\right.$., $128^{\circ} 57^{\circ} \mathrm{W}$.) and Mason River $\left(69^{\circ} 56^{\prime} \mathrm{N} ., 128^{\circ} 24^{\prime} \mathrm{W}\right.$.). Deltas of both rivers are important nesting and moulting areas for White-fronted Geese.' During the moulting period flightless geese are taken in traps and banded. Juveniles are sometimes captured and banded on shores of lakes and rivers after having been driven ashore by boats.

${ }^{*}$ Canadian Wildlife Service

Box 508,

Fort Smith, N.W.T.

XOE OPO
During my periods of fieldwork in the area, three interactions between Golden Eagles and White-fronted Geese were observed.

About 15 miles upriver from the mouth of the Anderson River on July 10, 1973, we saw eight White-fronted Geese going ashore ahead of our canoe. We made a landing to try to catch them. When we were following the geese we heard a startling noise and looked up just in time to see a Golden Eagle slam into the willows about 25 yards ahead of us. The eagle took off immediately and from near the eagle's impact site we captured a moulting White-front. The bird's back seemed only slightly bruised by the eagle but when the goose (incidentally, banded by us a few days earlier about 10 miles away) was released on the river it rapidly weakened and was dead when again picked up. An autopsy revealed a massive hemorrhage in the lung area. The eagle, by the absence of white in wings and tail, was judged to be an adult.

Near the mouth of the Mason River on July 15, 1973, broods of five and six White-fronts with their parents were seen from our canoe. The geese were on the edge of the river and at our approach two of the adults flew to a shallow tide pool a short distance away. A Golden Eagle stooped at these two geese and although contact was made with one of them, the geese flew off apparently unharmed. The eagle, perhaps unable to make a solid hit because of the last second evasive action by the goose, hit the tide pool in a 
rather steep angle and cartwheeled twice. The eagle then stood up, shook itself and flew off slowly to a nearby ridge. The eagle had a white tail with dark terminal band and was labelled as immature.

We had beached our canoe on July 19, 1973, along a channel about 7 miles south of the mouth of the Anderson River and I had just crouched down to pick up a White-front gosling when an eagle roared past me and slammed into 2-foot tall willows not 15 feet ahead of me. Two adult Whitefronts, hitherto unseen, flew out of the willows. The eagle, an immature Golden, was unable to get up because its wings were caught in the willows. I quickly got a banding net and caught it. After it was banded, the eagle flew away normally.

In each of these three cases we disturbed the geese and, in fleeing from us, they apparently failed to see the eagles until it was almost too late. Have eagles in this area learned that man's activities may force potential prey, otherwise not available, out of cover? It appears from the above thre separate and closely spaced incident that.well-intended disturbance by mat could contribute to mortality o moulting geese.

'BARRY, T. W. 1967. The geese of Anderson River. Unpublished PhD thesis. 212 p. Univ. ") Alberta, Edmonton.

"BENT, A. 1937. Life histories of North Americal hirds of prey. U.S. Nat. Mus. Bull. No. 167.

"BOEKER, L. and T. D. RAY. 1971. Goldes Eagle population studies in the southwest. Condo 73: $463-467$.

'CRAIGHEAD, J., C. CRAIGHEAD and D CRAIGHEAD. 1967. Sharing the lives of wild Golden Eagles. Nat. Geogr. 132: 420-439.

"HÖHN. E. O.. 1959. Birds of the mouth of the An derson River and Liverpool Bay. Nortlawes Territories. Cann. Field-Nat. 73(2): 93-114.

"McGAHAN. Jerry. 1968. Ecology of the Golde" Eagle. Auk 85(1): 1-12.

'MOLLHAGEN. A. R.. R. W. WILEY and R. L PACKARD 1972. Prey remains in Golden Eagle nests: Texas and New Mexico. Wildl. Mgint 36(3): 784-792.

"MURIE. Adolph. 1944. The wolves of Moun McKinley. U.S. Dept. Interior. U.S. Nat. Park: Serv.. Fauna Ser. No. 5

"SMITH. A. P. 1915. Birds of the Boston Mountains. Arkansas. Condor 17:41-57.

"'WHITFIELD. D. W. A.. D. W. DAVIS. J. M GERRARD and W. J. MAHER. 1969. Golden Eagles in central Saskatchewan. Blue Jay, 27 (2) 74.79.

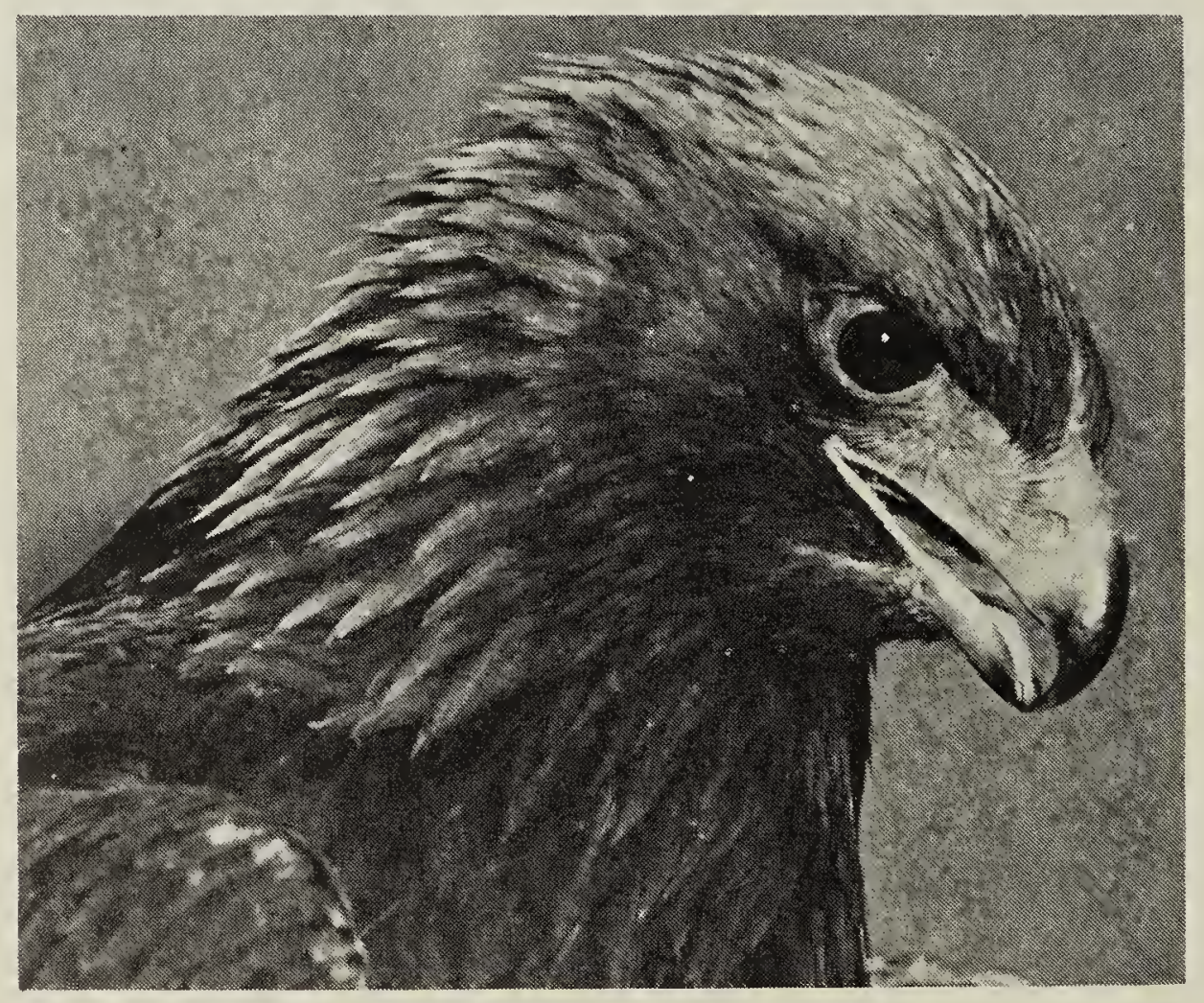

Golden Eagle

Fred Lahrman 